\title{
The hospitality sector: innovations addressing environmental concern
}

\author{
E. Szymańska \\ Department of Tourism and Recreation, \\ University of Technology in Biatystok, Poland
}

\begin{abstract}
There are several types of innovation in tourist enterprise, including products, processes, technology and organization. Product and technology innovations have been widely covered in the literature; whilst information about innovations of both processes and organization is far more limited. One other type of innovation receives scant attention: that is in the area of environmental concern.

The objectives of this article are: to determine the level of innovativeness within the hotel sector in terms of the implementation of environmental innovations, and to define the main types of innovations. In respect of these objectives, the following hypothesis is presented: innovativeness of the hotel sector in environmental terms depends somewhat on the extent of international co-operation. When calculating the level of innovatibility of hotel facilities one of the indicators recommended by the Oslo Manual (Bohdanowicz P., Turystyka a świadomość ekologiczna, Wydawnictwo Adam Marszałek, Toruń, 2006) was used, namely: the intensity of innovation. The author selected a random sample without replacement of registered hotel properties operating in Poland using an at random without replacement method. The diagnostic poll method was based on the survey questionnaire which included key questions about innovations introduced in the field of environmental protection. Research questions were constructed in the form of a half-open cafeteria. Research utilizing the diagnostic poll method was carried out on 100 hotels in Poland in order to verify this hypothesis.

The results obtained can be regarded as a basis for further detailed studies of innovativeness in tourism-based enterprises and so could well prove to be invaluable in running such businesses.
\end{abstract}

Keywords: environmental innovations, hotel sector, research. 


\section{Introduction}

The objectives of this article are: to determine the level of innovativeness within the hotel sector in terms of the implementation of environmental innovations, and to define the main types of innovations.

In respect of these objectives, the following hypothesis is presented: innovativeness of the hotel sector in environmental terms depends somewhat on the extent of international co-operation. A research utilizing the diagnostic poll method was carried out on 100 hotels in Poland in order to verify this hypothesis.

The results obtained can be regarded as a basis for further detailed studies of innovativeness in tourism-based enterprises and so could well prove to be invaluable in running such businesses.

\section{Innovations in the hospitality sector}

Innovation is a purposeful and organized seeking of changes and systematic analysis of opportunities to social or economic innovations which could be possible through such changes [6].

According to the Oslo methodology, an innovative company is the one which implements at least one innovation within a given period of research, usually a three-year research. Such innovation is understood as technological innovation, a new or improved product or new or improved process which is considered as a novelty, at least from the given entrepreneur's point of view [12].

In the literature on this subject we can encounter a variety of innovations; however Schumpeter's Theory of Economic Development seems to be the most suitable in this case.

Schumpeter's Theory is a base for the Oslo methodology and has been modified by the author, so that it distinguishes several types of innovations, concerning: product (including both products and services), process, technology (frequently identified with processes), organization and, natural environment protection. Figure 1, below, presents division of innovations within a tourist business.

Product innovations include all modifications, improvement and changes concerning tourist product, and especially introducing new tourist products to the market. Technology innovations involve introducing new technologies. Process innovations concern improvement of the main process in an organization, e.g. purchase of new machines which can give advantage over the competitors.

Organizational innovation includes the following changes [21]:

- implementation of advanced management techniques

- $\quad$ implementing essentially altered organizational structure

- introducing new or vitally changed organization's functioning strategies

Innovations concerning natural environment protection involve actions aiming at appropriate utilisation and renewal of environmental resources and elements [20]. 


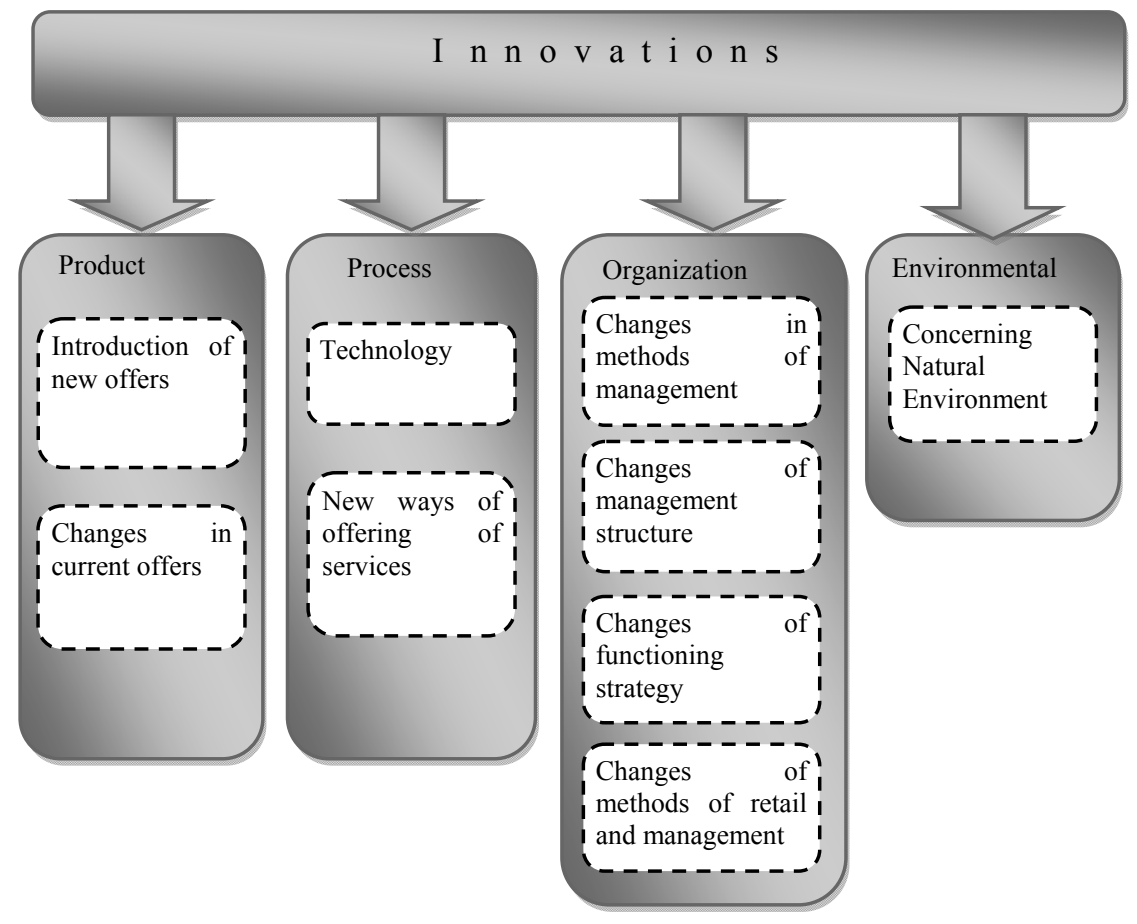

Figure 1: Innovations in tourist businesses. Source: author's own composition.

Innovatibility, however, is the process of denoting the ability of the company to continuous research and use of amendments in order to use them to create innovation.

\section{Environmental protection in tourism}

Tourism is the area of the economy, whose growth opportunities are very closely linked with the condition of the environment, and this, in turn, significantly depends on how you implement tourism [18]. However, there is a shortage of literature studies on the role of tourism as an agent of pro-environmental transformation in the economy [8].

Despite the fact that natural beauty has always been an important element in tourism development, the industry has long ignored the fact that their activities lead to environmental degradation [1]. The tourism industry was considered almost as "clean industry" [23]. This attitude has changed for many years and tourism is indicated as one of the greatest threats to the environment. An excessive amount of traffic on the routes and the routes leading to the travel destinations is a major factor which interferes with the natural environment and 
local residents. I. Pezdan believes that tourism involves more than half the total amount of traffic and consequently emissions [13]. The increasing consumption of resources, such as water and energy, as well as waste generation and pollution of these waters are further, negative effects of modern mass tourism [22]. Recently we have witnessed attempts to change this situation by developing environmentally-friendly forms, and especially ecotourism [9]. For example, J. Krippendorf characterizing the modern mass-tourism regards it as opposed to a soft tourism, which does not endanger the environment [17].

Representatives of the tourism industry appreciated the importance of environmental problems at the end of the seventies of the last century, what resulted, in 1979, in the appointment by the Executive Board of the World Tourism Organization the Committee for the Environment [13]. The task of the committee was the issue of protection of natural values. World Conference on Tourism, held in Manila in 1980 resulted in the publication of the Declaration on World Tourism ("Manila Declaration on World Tourism"). Two years later, the World Tourism Organization (WTO) and United Nations Environmental Programme (UNEP) jointly announced the "Declaration on Tourism and the Environment" ("Joint Declaration on Tourism and Environment"). In 1985 in Sofia, the "Manifesto of the Rights of Tourism (Tourism Bill of Rights") and "Code of Tourism" ("Tourism Code") were published. Another important document was the "Declaration on Tourism" ("The Hague Declaration on Tourism"); signed in Hague in 1989, which once again raised the issues of necessity to protect the environment from devastation by tourists [1]. However, a milestone was a United Nations conference in Rio de Janeiro, known as the "Earth Summit", which resulted in the creation of a global strategy for sustainable development. In 1995 at the International Conference on Sustainable Tourism held in Lanzarote, the Canary Islands, the Lanzarote Charter for Sustainable Tourism ("Lanzarote Charter on Sustainable Tourism") was declared [1], which initiated a study on the possibility of introducing the idea of sustainable tourism, which is the part of the idea of sustainable development. By sustainable development we understand the type of development which can meet the current generation's needs without diminishing the ability of future generations to meet theirs [2]. One of the well-known international enterprises in the field of environmental management systems is the "Green Globe", launched in 1994 by the World Travel and Tourism Council (WTTC). In 1999 the Green Globe 21 Certification was founded - an utterly independent organization which verifies business and tourist areas for compliance with environmental standards [7]. Referring to the question of sustainable development, P. Wight [16] says that many tourist companies attach increasing importance to the problem of accountability to the environment and treat economic reasons with equal importance to the social and environmental considerations.

More and more tourists attach importance to protecting the environment and they expect the same from the tour operator. With the increasing environmental awareness among tourists and local people, there is a growing concern for the environment. Environmental awareness is increasingly a critical factor in deciding where to rest. At present, there is not only the standard of tourism 
infrastructure and services that count, but also the quality of the environment [10]. To adapt to this trend, hoteliers introduce on their premises proenvironment solutions and tour operators seek to enter into contracts with facilities that meet the criteria for ecology and which are situated on the clean areas.

\section{Methodology of study}

On the basis of theoretical knowledge and practical experience derived from surveys carried out to examine the innovatibility of hotel facilities, recommendations on key aspects of collecting and analyzing statistical data on innovatibility in enterprises included in the Oslo Manual were used [12]. This approach is warranted, since this publication refers to the sphere of tourism services, to which reference may not be made with use of commonly applied indicators for measuring innovation, such as statistics on patents and indicators of resources spent on research and development (R \& D) [12]. When calculating the level of innovatibility of hotel facilities one of the indicators recommended by the Oslo Manual was used, namely: the intensity of innovation. In this publication it is assumed that the measurement of innovation in environmental protection in the hotel industry may serve the following variables that can be determined as the intensity of innovation:

- range of innovations introduced in the study area,

- plans for the introduction of environmental innovations.

This document is recommended to carry out tests on samples to which individuals should be selected at random (random sample surveys of the known probability of winning). The author selected a random sample without replacement of registered hotel properties operating in Poland at random without replacement method. The report prepared by the Institute of Tourism on behalf of the Central Statistical Office reports that at the end of 2006, 6718 room establishments were registered, among which there were 2,443 hotel properties (including registered hotels - 1370) [14]. To conduct statistical surveys on innovation, you can use different methods, and the Oslo Manual suggests surveys; this method was also applied by the author.

It is recommended that the length of the period under observation in the study of innovation does not exceed three years and is not shorter than one year, so the author of the research took three years to capture the frequency of innovation in tourism enterprises, in accordance with the assumption that an innovative enterprise is such that have introduced at least one innovation in three years (Based on Oslo Manual the innovative firm this is the firm which made minimum one innovation in the proper time (1-3 years); in this publication 3 years).

The survey questionnaire included two key questions about innovations introduced in the field of environmental protection. The first question concerned the innovations that have been implemented within three years by the respondents in companies they represented. The second question concerned the plans, which the company intends to undertake to protect, or reduce the impact 
on the environment. Research questions were constructed in the form of halfopen cafeteria, which proposed several variants to the respondents to reply with a showcase form of innovation not yet included in the proposal response. To evaluate extent of international cooperation each survey participant was asked in this matter. Research question was constructed in the form of closed cafeteria with three options. In total, the survey questionnaires were obtained from a hundred entrepreneurs.

\section{Innovations in the field of environmental protection in the hotel premises in the light of study}

Results of the first part of the discussion which concerned accomplished environmental innovations, the author compared with the large scale study conducted in the other European Union countries, particularly with similar studies carried out by P. Bohdanowicz [1].

In the hotel sector on a global scale about $40 \%$ from over 3000 respondents participating in the hospitality environmental studies conducted in 1998 by Horwath International and STR has confirmed the application of different methods of qualitative assessment of the impact of the facility on the environment, including energy and water saving, production and storage waste as well as volume and wastewater treatment [1]. According to J. Majewski, over $35 \%$ of hotel properties around the world implement comprehensive environmental programs [11]. On the other hand, test results are not so optimistic, for example, research conducted by Pricewaterhouse Coopers among the hotels in Europe showed that although $80 \%$ of hotel companies develop proenvironment policies, only 27\% implemented an Environmental Management System [4]. Every eighth respondent pledged to negotiate with suppliers on the environment and its protection, $45 \%$ claimed to publish environmental reports, while $18 \%$ intend to do so soon. P. Bohdanowicz in her studies performed on the hotel premises in Poland, Sweden and Croatia reduced the scope of these environmental initiatives under three main groups of issues: energy saving, water saving and responsible waste management. The results of these studies in relation to Polish hotels showed that $83.9 \%$ of respondents demonstrated energy savings. In terms of water saving the percentage is slightly lower and amounted to $79 \%$. Least hotels declared the responsible management of waste, and they accounted for $77.4 \%$ of the surveyed hotels in Poland. It should be emphasized that the studies were conducted in 2002 and 2003 (in two stages), and since then the results of last group of issues could change considerably in conjunction with those regulations of the Sanitary and Epidemiological Station (Pol. Sanepid) [19], which make it illegal for the food serving premises to donate food remains as domestic animals fodder.

Among the initiatives designed to conserve water, the programme of towel exchange on request - according to P. Bohdanowicz - is well established at the moment in most of the European countries. This programme not only provides the energy and water saving, but also leads to a reduction in the use of detergents and extends the life of materials. This program is applied in Poland, in the light 
of research by $\mathrm{P}$. Bohdanowicz, by $64.5 \%$ of respondents, slightly above the European average, which was $60.5 \%$. All Eco-certified hotels and every eighth hotel in Germany without certification declared to possess this program. The results of these studies can be compared with tests carried out by the author in the field of environmental innovation introduced in hotel facilities in Poland. The author provided research on innovation of entrepreneurs tourism, where the most innovative in environmental protection were the objects of hospitality.

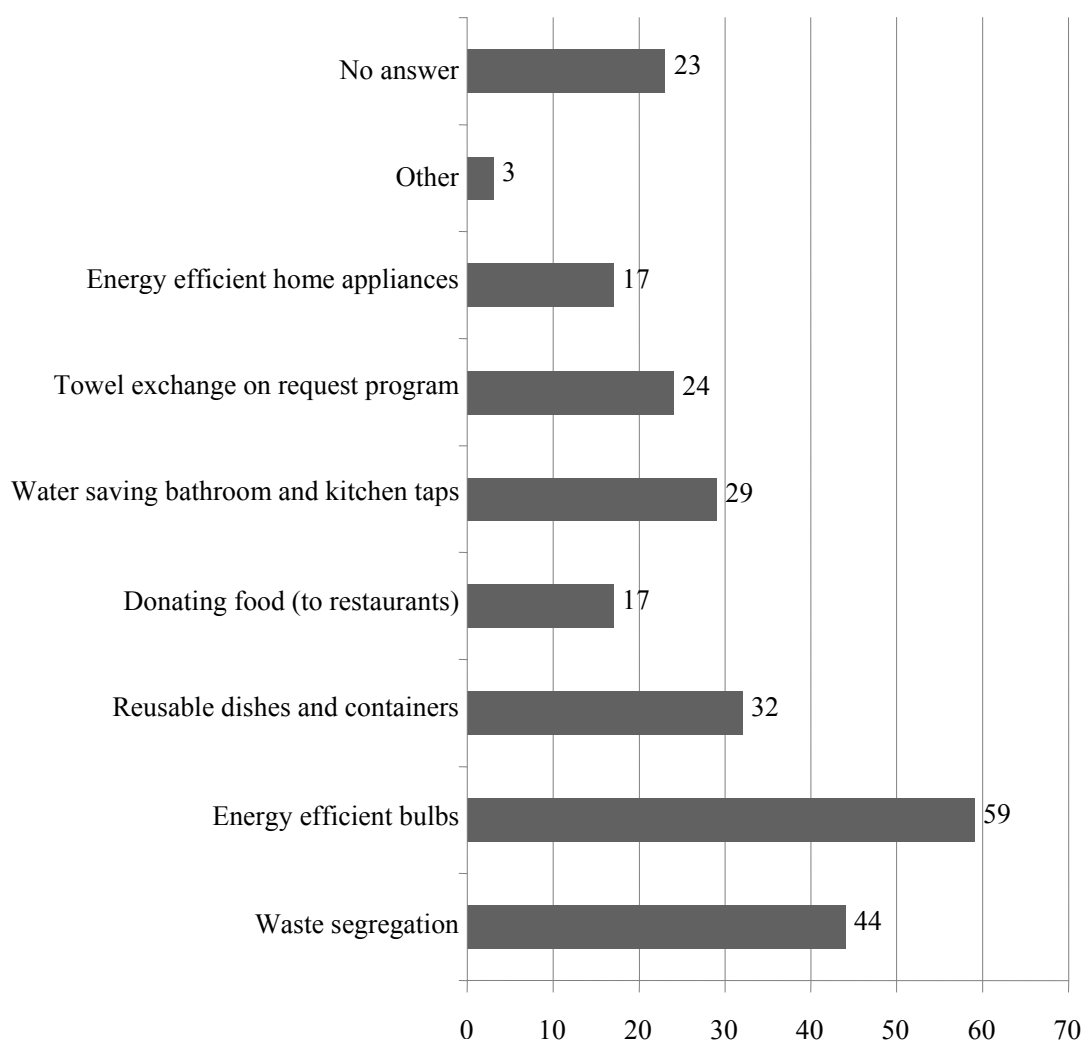

Figure 2: Activities of the studied hotel premises for the scope of environmental protection (\%). Source: Author's own composition based on the research.

Among the proposed activities most popular among the respondents was the use of energy-efficient lighting, which was introduced by $59 \%$ of hotel facilities. P. Bohdanowicz's results were in this area a bit more optimistic for Poland and amounted to $70 \%$ of hotel operators, with $55.2 \%$ for Europe. In the second place was the segregation of waste, which was done by $44 \%$ of respondents. The relevant studies suggest $\mathrm{P}$. Bohdanowicz 30.6\% for hotels using the segregation 
of waste in Poland, with an average of $47.5 \%$ for Europe. Reusable Packaging in Poland were used by $50 \%$ of hotels, the average for Europe was 32.2\% [1]. These results, for the test conducted by the author, were significantly lower than the results obtained by P. Bohdanowicz for hotels in Poland and remained at the level of European average of $32 \%$. Water saving batteries (with aeration) and toilets (dual flush) were used by $44.4 \%$ of hotels in Poland, as it is shown in a study carried out by P. Bohdanowicz, while the EU average was 36\%. Sweden appeared as the best in this respect, where $61.8 \%$ of facilities had installed such equipment. However, the results obtained from the hotels studied by the author were far less optimistic and gave 29\%. According to P. Bohdanowicz's publication, energy-saving and efficient home electronics and appliances in Poland possessed $41.9 \%$, while in Europe $45.6 \%{ }^{40}$. The result obtained by the author again was much lower and amounted to only $17 \%$. Donation of food can not fully be studied with comparison method due to different rules applied in different countries and their changes during the research period in question.

Innovativeness of the hotel sector in environmental terms may depend somewhat on the extent of international co-operation. To evaluate extent of international cooperation each survey participant was asked to select one out of three possible answers: extensive international cooperation, sporadic international cooperation, no international cooperation. The research has found that the greatest amount of environmental innovations was introduced by hotels that were involved in extensive international cooperation (average 2.31 innovations). Second greatest amount of environmental innovations was introduced by hotels not involved in any international cooperation (average 2.27 innovations). The least number of environmental innovations was introduced by hotels sporadically involved in international cooperation (average 2.15 innovations).

The results of individual tests, as pointed out above - in some areas differ quite significantly, but differences may arise mainly from differences between the sample singled research (e.g. only hotels, then on the other, a diverse group of hotel facilities, including hotels, motels, resorts and pensions) and the period of testing (before and after Poland's accession to the European Union). But the overall conclusion is similar: the owners of tourism enterprises are aware of the gravity of the problems related to environmental protection and strive to realize them.

\section{Planning innovation in the hotel sector on the example of hospitality facilities in Poland}

Environmental innovation activities at the premises of hospitality demonstrate awareness of many of the entrepreneurs in the sector of necessity for such changes. The author advanced even further in her inquiry and attempted to examine the plans of this group of companies regarding environmental innovation. The scope of planned activities in this area is shown in Figure 3. 


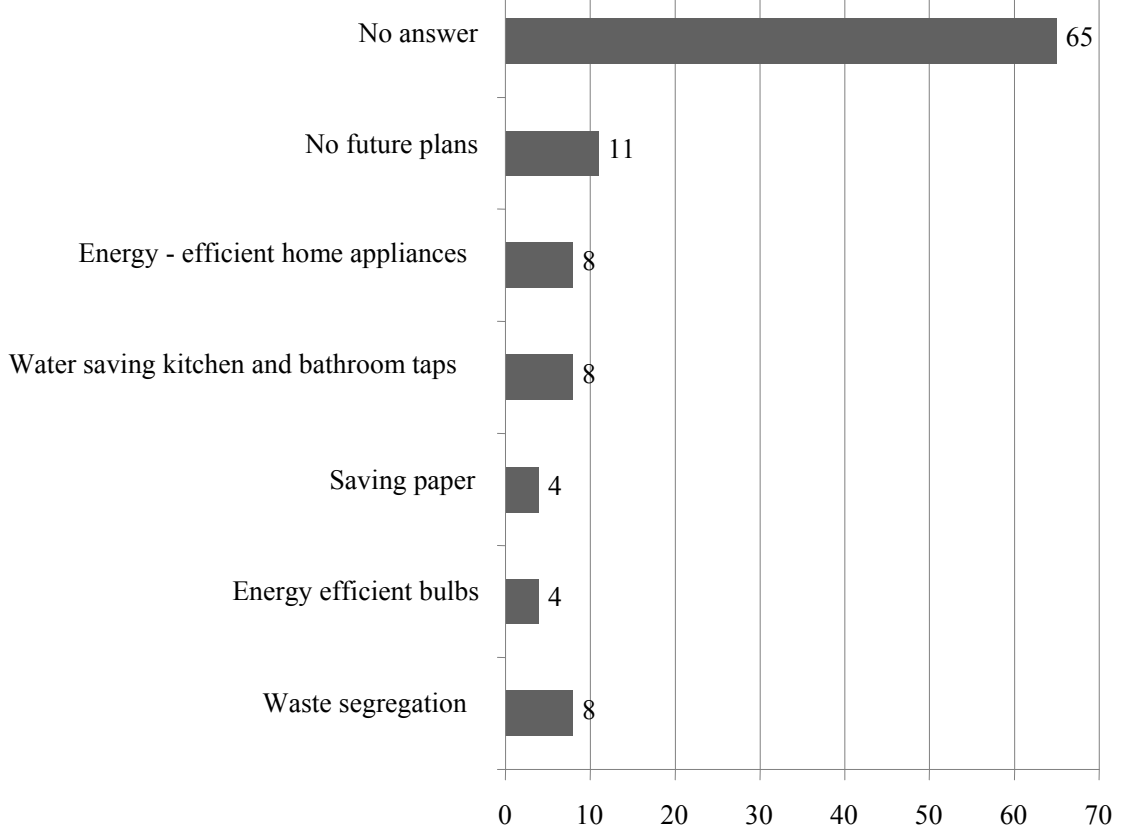

Figure 3: Planned environmental activities of the studied hospitality businesses (\%). Source: author's own composition based on the research.

Results of studies on the plans to innovate in the field of environmental protection by the hotel facilities in Poland indicate a very low interest in this type of business innovation, to the extent that it is even difficult to subject it to scientific inference, since $59 \%$ of respondents did not give any answer here. Only eight subjects $(8 \%)$ planned to introduce energy-efficient consumer electronics and household appliances, waste segregation and installing waterefficient kitchen and bathroom taps.

Twice as few operators (4\% of respondents) declared that they save paper and an equal number admitted using energy efficient light bulbs. A number of companies $(10 \%)$ had no plans for the protection of the environment. It is difficult on the basis of such fragmentary results to draw a meaningful conclusion, however, the importance of this matter inclines the author draw one main conclusion - namely, it is necessary for the entrepreneurs to change their attitude to the area of business innovation in environmental protection. 


\section{Conclusion}

The issue of innovation for environmental protection in the hospitality industry is relatively new in literature, as traditionally it is considered that the manufacturing companies and households to a much greater degree interfere in this environment. Most respondents pointed to the innovations introduced in the installation of energy efficient light bulbs, the next was the segregation of waste, in the third place, the dishes and reusable containers, followed by water-saving kitchen and bathroom taps. Then, the next innovation was the installation of energy-efficient consumer electronics and appliances, and at the end of the list was an exchange of towels on request. It should however be taken into account the possibilities that lie in tourist enterprises, whose number and area of activity extends every year. The research has found that the innovativeness of the hotel sector in environmental terms does not depend directly on the extent of international co-operation but the greatest amount of environmental innovations was introduced by hotels that were involved in extensive international cooperation.

Thus research and activities in this area should be significantly expanded, not only in terms of simple actions suggested above, but also in terms of awarenessraising within business, because, as the author's research has shown, the level of awareness is unfortunately very low, as evidenced by very modest plans by the hotel facilities for innovation in environmental protection.

\section{References}

[1] Bohdanowicz P., Turystyka a świadomość ekologiczna, Wydawnictwo Adam Marszałek, Toruń, 2006.

[2] Brundtland G. H., Our Common, Future, World Commission on Environment and Development, Oxford University Press, Oxford, 1987.

[3] Ceballos-Lascurain H., Tourism, Ecotourism and Protected Areas: the State of Nature Based Tourism Around the World and Guidelines for Its Development, World Conservation Union, Gland, 1996.

[4] Clark J. \& Siddall L., European Hotel's Implementation of Environmental Policies, Hospitality Directions - Europe Edition, July 2001, Pricewaterhouse Coopers.

[5] Definicje pojęć z zakresu statystyki naukowej i techniki, GUS, Warszawa, 1999.

[6] Drucker P. F., Innowacja i przedsiębiorczość. Praktyka i zasady, PWE, Warszawa, 1994.

[7] Holden A., Environment and Tourism, Routledge, London, 2000.

[8] Jędrzejczyk I., Ekologiczne uwarunkowania $i$ funkcje turystyki, Wydawnictwo "Śląsk", Katowice, 1995.

[9] Kurczewski R., Ecotourism - Chances and Threats, "Ecology International Journal for Ecology Problems of the Biosphere" (4), 2001.

[10] Kurek W., Turystyka zrównoważona - turystyka przyszłości, [in:] Turystyka czynnikiem integracji międzynarodowej, eds. J. Biliński, \& D. 
Sawaryn, Wydawnictwo Wyższej Szkoły Informatyki i Zarządzania, Rzeszów, 2003.

[11] Majewski J., Hotelarstwo przyjazne środowisku - sposobem na obniżenie kosztów, "Rynek Turystyczny", (7), 1999.

[12] Oslo Manual, OECD/Wspólnoty Europejskie/Eurostat, 2005.

[13] Pezdan I., Wybrane tendencje rozwojowe turystyki w obliczu wyzwań XXI wieku, [in:] Ekonomiczne i organizacyjne aspekty rozwoju turystyki, eds. J. Krupa, T. \& Soliński, Wydawnictwo Wyższej Szkoły Informatyki i Zarządzania, Rzeszów, 2004.

[14] Rocznik Statystyczny Rzeczypospolitej Polskiej 2008, GUS, Warszawa. 2008.

[15] Vogl A., 1998 Horwath Worldwide hotel industry study, Conference materials "IH\&RA 36th Annual Congress", Manila, 1998.

[16] Wight P., Tools for Sustainability Analysis In Planning and Managing Tourism and Recreation in the Destination, [in:] Sustainable Tourism: A Geographical Perspective, eds. C. M. Hall \& A. Lew, Longman, Harlow, pp. 75-91.

[17] Krippendorf J., Die Ferienmenschen. Fur ein neues Verstandnis von Freizeit und Reisen, Orell Fussli, Zurich Und Schwabisch Hall, 1984.

[18] Wojanowska J., Turystyka zrównoważona: przemysł turystyczny a zrównoważony rozwój, [in:] Turystyka czynnikiem integracji międzynarodowej, eds. J. Biliński \& D. Sawaryn, Wydawnictwo Wyższej Szkoły Informatyki i Zarządzania, Rzeszów, 2003.

[19] www.gis.gov.pl

[20] www.mos.gov.pl.

[21] www.oecd.org/dataoecd.

[22] www.pot.gov.pl.

[23] Zaręba D., Ekoturystyka: wyzwania i nadzieje, Warszawa, 2000. 